CHEMICAL SEPARATIONS PROCESSES FOR PLUTONIUM AND URANIUM (TID-4500, 16th Ed.)

\title{
ANION EXCHANGE IN A LARGE-SCALE AGITATED BED
}

\author{
by \\ Vincent P. Caracciolo \\ September 1961
}

E. I. du Pont de Nemours \& Co.

Explosives Department - Atomic Energy Division

Technical Division - Savannah River Laboratory

Printed for

The United States Atomic Energy Commission

Contract AT(07-2)-1

Approved by

W. E. Winsche, Research Manager

Separations Engineering Division 


\section{DISCLAIMER}

This report was prepared as an account of work sponsored by an agency of the United States Government. Neither the United States Government nor any agency Thereof, nor any of their employees, makes any warranty, express or implied, or assumes any legal liability or responsibility for the accuracy, completeness, or usefulness of any information, apparatus, product, or process disclosed, or represents that its use would not infringe privately owned rights. Reference herein to any specific commercial product, process, or service by trade name, trademark, manufacturer, or otherwise does not necessarily constitute or imply its endorsement, recommendation, or favoring by the United States Government or any agency thereof. The views and opinions of authors expressed herein do not necessarily state or reflect those of the United States Government or any agency thereof. 


\section{DISCLAIMER}

Portions of this document may be illegible in electronic image products. Images are produced from the best available original document. 


\begin{abstract}
An agitated ion exchange column was adapted for use in a large radiochemical separations plant. Tests with nonradioact1ve solutions showed that 1 on exchange resin could be charged to and discharged from the column through typical plant piping and without the use of mechanical valves. With the agitator turning, the bed passed solutions containing 400 ppm of finely divided silica whereas a fixed bed became plugged. The pressure drop through the column and the absorption characteristics of an anionic complex of thorium nitrate were compared under agitated, pulsed, and fixed bed conditions.
\end{abstract}




\section{CONTENTS}

$\begin{array}{lr}\text { Introduction } & \frac{\text { Page }}{} \\ \text { Summary } & 4 \\ \text { Discussion } & 4 \\ \text { Experimental Columns to Obtain Design Data } & 5 \\ \text { Prototype Column } & 5 \\ \text { Column Design and Mode of Operation } & 6 \\ \text { Hydraulic Characteristics } & 6 \\ \text { Absorption Characteristics } & 7 \\ \text { Procedure for Addition of Resin to the Column } & 8 \\ \text { Procedure for Removal of Resin from the Column } & 9 \\ \text { Glossary of Terms } & 9 \\ \text { Appendix } & 10 \\ \text { Bibliography } & 11\end{array}$

\section{LIST OF FIGURES}

\section{Figure}

1 Experimental Ag1tated Bed

2 Effect of Agitation and Thorium Concentration on Absorption Characteristics

3 Effect of Contact Time on Absorption Characteristics 20 to 50 Mesh "Dowex" 1-X4 Resin

4 Effect of Contact Time on Absorption Characteristics 50 to 100 Mesh "Dowex" 1-X4 Resin

5 Pulsed Ion Exchange Column

6 Effect of Air Pulse on Column Plugging

7 Absorption Characteristics of a Pulsed Bed

8 Prototype Column

9 Effect of Ag1tation on Bed Plugging 20

10 Pressure Drop for Operation as a Fixed Bed 21

11 Pressure Drop for Operation as an Ag1tated Bed 22

12 Absorption Characteristics for Operation as a Fixed Bed 23

13 Typical Elution Characteristics 24

14 Absorption Characteristics with a Reduced Volume of Resin 25

15 Elution Characteristics with a Reduced Volume of Resin 26

16 Resin Unloading 


\title{
ANION EXCHANGE IN A LARGE-SCALE AGITATED BED
}

\author{
INTRODUCTION
}

The use of a conventional ion exchange column for the recovery of products from highly radioactive solutions is complicated by remote operation and frequently by finely divided solids which rapidly plug the resin bed. An ion exchange column that could tolerate solids in the feed solution was reported by Bartels, et al( 1 ). Bartels successfully recovered streptomycin from a yeast broth containing solids by means of an agitated bed in which the resin was contained by a screen with tapered holes. A paddle swept the screen to prevent plugging by the fine solids.

The purpose of the work described in the report was to show by means of pilot plant tests that an ion exchange column similar to that described by Bartels(1) had characteristics that made it sultable for use in a radiochemical plant. A moderate absorption efficiency was acceptable, and finely divided solids were expected in the feeds.

\section{SUMMARY}

A.l agltated ion exchange column was adopted and found to be suitable for use in a radiochemical plant. Tests were made on columns with resin capacities of 7,11 , and 25 liters. "Dowex" and "Permutit" anion resins with bead sizes from 20 to 80 mesh were used. Nonradioactive solutions contalning an anionic complex of thorium nitrate were used to demonstrate the absorption and elution characteristics of the beds.

Resin was charged to and discharged from the 25-11ter column through piping typical of a remotely maintained plant. Air-pressured weirs were demonstrated to be satisfactory substitutes for mechanical valves. Feeds containing $400 \mathrm{ppm}$ of silica caused the beds to plug when not agitated but were free flowing when the beds were agitated.

The columns had the typical breakthrough characteristics of fixed beds when not agitated but acted as differential contactors when agitated. With the column being agitated to pass solids, the concentration of thorium in the absorption effluent increased to $20 \%$ of the feed concentration after ten bed volumes had passed through with an average residence time of 10 minutes. Other data are avallable(2) that show that this loss would be less than 5\% for an anionic nitrate such as plutonium, which is absorbed by the resin much more strongly than is thorium. When the bed was pulsed instead of agitated, sollds were passed equally as well, and the thorlum concentration in the effluent was less than 5\% of the feed concentration after ten bed volumes had passed through. Losses were approximately $5 \%$ after 25 bed volumes when the column was operated as a fixed bed.

Detailed procedures were established for operating the column under remote maintenance conditions. 


\section{DISCUSSION}

\section{EXPERIMENTAL COLUMNS TO OBTAIN DESIGN DATA}

The hydraulic and chemical characteristics of the agltated bed were determined in a glass column, 9.5 inches in diameter, to obtain data for the design of a prototype column. The column contained 7 liters of "Dowex" 1-X4 anion resin (the resin is measured as the bulk volume in the nitrate form). The resin is retalned by a 100-mesh perforated plate at the bottom of the bed. This plate was swept by a flat paddle to prevent plugging by resin and/or solids. The use of a perforated metal plate with tapered holes or slots (7\% open area) minimized plugging by resin fines or solids. With the smaller dimensions of the tapered hole facing the resin, fine particles went through the plate unimpeded, and larger particles that would blind an ordinary screen were swept away by the movement of the liquid. The outlet welr was set at a helght sufficlent to maintain a ratio of liquid volume to resin volume of at least 1.25 to permit agitation of the resin. The bed is shown in Figure 1 .

The hydraulic and chemical performances of the bed were evaluated wlth "Dowex" $1-\mathrm{X} 4$ anion resin in the nitrate form. An anionic complex of thorium nitrate was used as the absorbable materlal, and absorption occurred by exchange of the nitrate ion on the resin for the anionic complex of thorium. A typical solution contained $6.5 \mathrm{~N} \mathrm{HNO}_{3}, 2 \mathrm{M} \mathrm{NaNO}_{3}$, and approximately $500 \mathrm{ppm}$ of finely divided silica.

The column readily passed the solids without any evidence of plugging or bulldup of solids in the bed. An agitator speed of at least $100 \mathrm{rpm}$ was required to ensure the passage of solids through the screen. Resin attrition and subsequent loss through the screen were negligible. The absorption characteristics of the bed are summarlzed in Figures 2, 3, and 4, in which the instantaneous loss of thorium is plotted against throughputs (see the Glossary for definition of terms). Figure 2 shows that absorption is not improved by increased agitation above that required to pass solids and that the loss of thorium is independent of its concentration in the range 0.04 to $0.8 \mathrm{~g} / \mathrm{I}$. A reasonable contact time was determined to be approximately 15 minutes when 20- to 50-mesh "Dowex" $1-X 4$ resin was used; longer contact times gave negligible improvement in recovery. This effect of contact time on instantaneous loss is shown in Figure 3. Equivalent recovery could be achieved with a contact time of only 3 minutes with 50 - to 100-mesh resin (Figure 4 ).

For the special case in which the feed solution had a higher density than the resin, the bed floated and expanded even when subjected to a downward flow; this action allowed solids to pass through the bed. The absorption characteristics of the expanded bed approached those of a fixed bed. The improved performance of the floating bed would make possible the recovery in a single unit of products having a low distribution coefficient, instead of necessitating the use of multiple 
agitated columns. Although the bed readily passed the solids, the bottom screen, used to retain the resin, plugged with particles of resins and solids that were gradually carried down. This difficulty was overcome by pulsing the column so that liquid passed back and forth through the bottom perforated plate and forced the fine solids through the plate. The pulses were generated by cyclic variations of the air pressure to the waste outlet weir. A restricting orifice placed in the fackleg leaving the weir prevented dissipation of the pulse energy out the outlet welr. A schematic diagram of the pulsed ion exchange column is shown in Figure 5. The outlet weir was positioned to provide below the floating bed a free space that was equal to the fixed bed thickness. This volume was required to prevent compaction of the resin against the bottom screen when the downward flow expanded the bed.

The column was tested with a $\mathrm{HNO}_{3}-\mathrm{NaNO}_{3}$ solution having a sp gr of 1.3 and contalning $500 \mathrm{ppm}$ of finely divided silica. The column contained "Dowex" 1-X4, 20- to 50-mesh resin that had a sp gr of approximately 1.25. The ability of the pulsed column to pass solids is shown in Figure 6. The efficiency of absorption for a pulsed bed approached that of a fixed bed (Figure 7). During elution, the elutriant flowed down through the column, which was operated as a fixed bed. The addition of the less dense elutriant caused the resin bed to sink slowly as the dense feed solution was displaced. The elution characteristics, after the bed settled as a plug to the bottom of the column, were the same as observed for a fixed bed. Four throughputs were sufficient to elute greater than $95 \%$ of the absorbed thorlum. After elution the floating bed was regenerated by feeding three bed volumes of wash solution of high specific gravity and agitating the bed. The floating bed re-formed when the agltator was stopped.

\section{PROTOTYPE COLUMN}

\section{COLUMN DESIGN AND MODE OF OPERATION}

On the basis of results obtained from the semiworks test columns and laboratory studies, a prototype ion exchange column was bullt and tested to show the feasibility of recovering products from highly radioactive solutions in a remotely maintained facility. The criteria used in the design were as follows:

1. The column should not use valves to separate waste and product streams.

2. The addition and removal of resin by remote control should be simple.

3. The column should operate either with agitation to pass solids or with a conventional fixed bed. 
The column was a stainless steel cyllnder, one foot in diameter and two feet high, with an agitator and a perforated metal plate at the bottom to retain the resin. The column had a maximum resin capacity of 25 liters. All solutions entered through the top feed inlet and left the bottom through one of the two outlet weirs. The outlet weirs were designed to operate as valves to direct the flow from the column. The welrs had a fackleg on the exit side of the welr box so that air could be introduced into the weir to develop pressure greater than that avaliable from the liquid head in the column, and thus effectively to stop the flow. The waste outlet weir was positioned to maintain a ratio of liquid volume to resin volume of at least 1.3 for easy agitation. The product outlet weir was set three inches higher than the waste outlet, which also contained a dip leg so that the density difference of 0.25 between the 7 to $9 \mathrm{~N} \mathrm{HNO}_{3}$ feed solution and the $0.3 \mathrm{~N} \mathrm{HNO}_{3}$ elutriant would automatically direct the flow without the use of air pressure. Air pressure was required only when solutions of different density were used or when both weirs had to be sealed during resin removal to direct flow out the column overflow. In overflowing the column the solution would bypass the bottom retaining screen and allow the resin to flow out the column as a slurry. An air bubbler was placed in the column to indicate the liquid level during operation. The prototype column is shown in Figure 8 .

\section{HYDRAULIC CHARACTERISTICS}

The ability of the column to pass solids was tested with a 25-liter resin charge of "Dowex" I-X4, 20- to 50-mesh resin. The feed solution was $8 \mathrm{~N} \mathrm{HNO}_{3}$ contalning $350 \mathrm{ppm}$ of finely divided silica. When the column operated as a fixed bed it plugged rapidly after only two bed volumes of feed had passed through the column. At this point the agitator was turned on and the bed immediately became unplugged. The liquid level dropped sharply and became constant for the remainder of the run. This effect of agitation is shown in Figure 9.

The pressure drop of the lon exchange bed as a function of flow rate and resin volume was determined for both flxed and agltated beds. The pressure drop through the fixed bed was directly proportional to the mesh range, bed depth, and the flow rate. The data are summarized in Figure 10. The pressure drop through the agitated bed was very low when the bed was completely agitated and was a function of the resin mesh size, the flow rate, and the liquid-to-resin ratio. The data are summarlzed in Figure 11 for "Permutit" SK, 40- to 80-mesh, and "Dowex" 1-X4, 20- to 50-mesh. The sens1t1vity of the pressure drop to the downward flow velocity increased as the resin size decreased. This effect was caused by blinding of the screen with fine resin carried down by the increased liquid velocity. The effect can be reduced by increasing the degree of agitation. The rate of resin attrition, the pressure drop, and the absorption characteristics of the bed were dependent on the degree of agitation. In a test in which the top paddle was removed the bed would not slurry and the attrition rate of 
the resin became extremely high; the rate at which resin was lost from the column was about $1 / 4$ per cent per hour ... compared to an undetectable loss when both paddles were used. The high attrition rate was caused by grinding of the compacted resin between the padde and the bottom plate.

Two paddles operating at $150 \mathrm{rpm}$ give sufficient agitation to allow the passage of solids, a low resin attrition, and good absorption characteristics. Examination of the resin after 40 hours of agitation and of the small amount of fines collected from the waste solution leaving the column showed that resin attrition was negligible.

The pressure drop data for both agitated and fixed beds were readily reproducible and could be used with accuracy adequate to estimate the amount of fresh resin present in a column and to determine whether the column was empty after a resin removal operation.

\section{ABSORPTION CHARACTERISTICS}

The absorption characteristics of the prototype column were evaluated for both agitated and flxed bed conditions with $8 \mathrm{~N} \mathrm{HNO}_{3}$ containing thorium nitrate. The performance of the agitated bed containing the maximum resin charge of 25 liters was equivalent to that of the experimental column. The agitated bed performed equally well with elther the "Dowex" $1-\mathrm{X} 4$ or "Permutit" SK resin.

The flush step with $8 \mathrm{~N} \mathrm{HNO}_{3}$ to remove solids and other contaminants from the bed could be run elther with continuous agltation or by agitating only during the initial two throughputs to remove solids, and then operating as a fixed bed. Flushing losses averaged 0.5 to $1.0 \%$ per bed volume for the thorlum and were about the same whether the flush was made with agitated or fixed bed conditions.

The column was successfully operated as a fixed bed and the characteristics were typical of a conventional fixed bed; therefore, plug flow was readily achleved and channeling was not a problem (Figure 12). The loss remained essentially zero for approximately 15 throughputs; at this point breakthrough occurred. Flushing of the fixed bed after loading follows the same curve as feeding because the washing cycle tends to spread out the absorption band and losses increase rapidly with the number of throughputs. An agitated flush is not recommended after fixed bed loading, since high losses occur when the fixed bed profile is destroyed by agitation.

The elution characteristics of the fixed bed with downflow were the same as those of conventional ion exchange columns. Four throughputs removed more than 95\% of the absorbed thorium, as shown in Figure 13. 
Operation of the column with only one-half of the normal 25 liters of resin proved that the column was very flexible as designed. It performed satisfactorily without any change in the position of the outlet weirs. The agitated and fixed bed results are presented in F1gures 14 and 15. An 1ncrease of four gallons in the displacement cut was required for the shallow bed during elution because of the increased volume of solution above the settled resin.

PROCEDURE FOR ADDITION OF RESIN TO THE COLUMN

Resin was added to the column by slurrying the resin in a solution of approximately the same specific gravity as the resin and adding it through the feed line. The resin was retalned by the bottom screen, and the solution flowed to waste. A detalled description of the procedure is given in the Appendix.

Resins finer than 80 mesh could not be used because they would blind the 100-mesh screen, even when agltated, and the column would overflow.

All the resins were successfully loaded wlth water; however, water was not used routinely since the lower density might cause resin to be held up in the traps located in the addition line. The cholce of solutions to use during resin addition and flushing, as well as the rate of addition or flushing, will depend on the type of resin being added. The aqueous solution used for "Dowex" $1-\mathrm{X} 4$ and "Permutit" SK was 26 wt $\% \mathrm{NaNO}_{3}$ or 22 wt $\% \mathrm{Al}\left(\mathrm{NO}_{3}\right)_{3}$, each of which has a sp gr of 1.2 . However, $\mathrm{Al}\left(\mathrm{NO}_{3}\right)_{3}$ solution was not used for the "Dowex" $50 \mathrm{~W}$ since it is a cation resin and the aluminum ion would exchange with the sodium ion in the resin. Subsequent removal of the aluminum would be difficult.

PROCEDURE FOR REMOVAL OF RESIN FROM THE COLUMN

Resin was removed from the column by slurrying the resin in the column with a solution of equivalent specific gravity and directing the flow out the overflow pipe in the neck. A detalled description of the procedure is given in the Appendix.

The beds unload very well and follow a calculated unloading curve for perfect mixing (Figure 16) if the specific gravity of the resin and the solution are reasonably matched. Effective unloading was obtained with solutions having specific gravities varying \pm 0.05 from that of the resin.

The "Dowex" 1-X4 and "Permutit" SK resins were removed by either 26 wt \% $\mathrm{NaNO}_{3}$ or 22 wt $\% \mathrm{Al}\left(\mathrm{NO}_{3}\right)_{3}$. These solutions have a sp gr of 1.2 , which approximates the specific gravity of the resins. Five vessel volumes removed approximately 99\% of the resin. The use of water for unloading the "Permutit" SK and "Dowex" 1-X4 resins resulted in poor mixing, which permitted the solution to bypass the resin. When water was used, approximately ten vessel volumes were required to remove $99 \%$ of the resin. 
The removal of the "Dowex" $50 \mathrm{~W}$ cation resin proved to be more difficult because its specific gravity is approximately 1.4. An unloading solution of 40 wt $\% \mathrm{NaNO}_{3}$ or 33 wt \% Al( $\left(\mathrm{NO}_{3}\right)_{3}$ having a sp gr of 1.32 was required to give sufficient mixing and to minimize the amount of solution allowed to bypass the resin. Ten vessel volumes were required to remove approximately 99\% of the resin. The $\mathrm{Al}\left(\mathrm{NO}_{3}\right)_{3}$ solution proved to be more effective in removing the resin because 1 ts higher viscosity minlmized settling of the resin in the column during unloading.

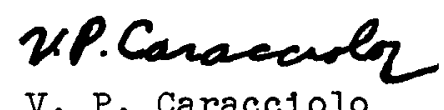

V. P. Caracciolo

Separations Englneering Division

\section{GLOSSARY OF TERMS}

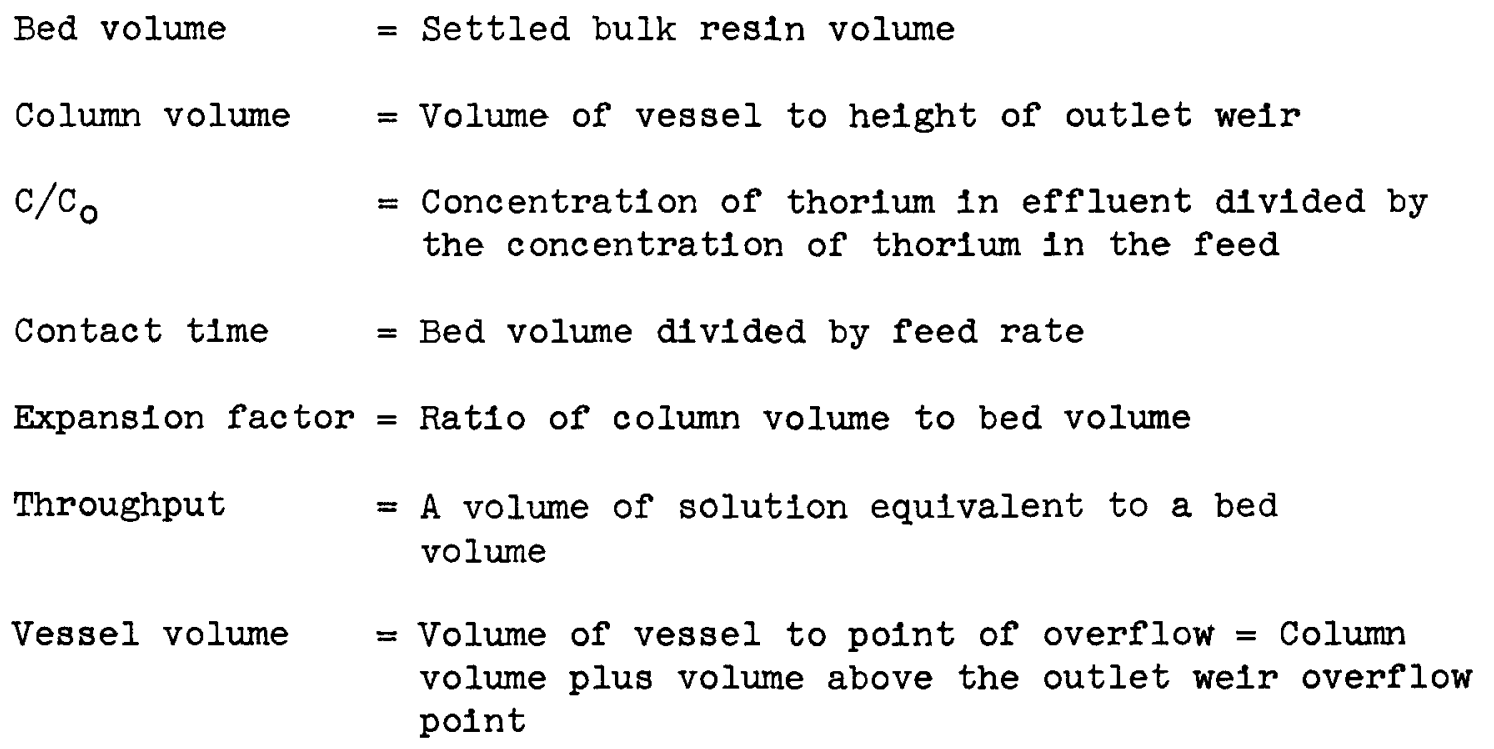




\section{APPENDIX}

PROCEDURE FOR RESIN ADDITION

The product outlet weir was sealed by applying air pressure of approximately 10 inches of water. This directed all the flow from the bed out the waste outlet weir and into the waste tank. A resin charge of 25 liters was slurried with flve bed volumes of solution having the approximate specific gravity of the resin (1.2 to $1.3 \mathrm{sp} \mathrm{gr}$ for "Dowex" $1-X 4$ and "Permut1t" SK and 1.2 to 1.4 for "Dowex" 50W). The column was then flushed with three column volumes of solution used in making the resin slurry at approximately $1.5 \mathrm{gal} /(\mathrm{min})\left(\mathrm{ft} \mathrm{t}^{2}\right)$. The column agltator was started and the slurry was added to the column at a rate not exceeding $1.5 \mathrm{gal} /(\mathrm{min})\left(\mathrm{ft}^{2}\right)$ for 20 - to 50 -mesh or $0.7 \mathrm{gal} /(\mathrm{min})\left(\mathrm{ft}^{2}\right)$ for 40 - to 80 -mesh resin. The resin addition was followed by a line flush to remove all resin from the feed lines. The bed agitator was stopped and the solution that was used for loading was removed from the bed with ten bed volumes of $0.35 \mathrm{M} \mathrm{HNO}_{3}$ at a flow rate not exceeding $1.5 \mathrm{gal} /(\mathrm{min})\left(\mathrm{ft}^{2}\right)$ for 20 - to $50-\mathrm{mesh}$ resin or $0.6 \mathrm{gal} /(\mathrm{min})\left(\mathrm{ft}^{2}\right)$ for 40 - to 80 -mesh resin.

\section{PROCEDURE FOR RESIN UNLOADING}

Alr pressure (19 inches of water for solution of $1.2 \mathrm{sp} \mathrm{gr}, 21$ inches of water for solution up $1.32 \mathrm{sp} \mathrm{gr}$ ) was applied to the product outlet weir and the agitator was started. The bed was flushed with three bed volumes of unloading solution at $1.5 \mathrm{gal} /(\mathrm{min})\left(\mathrm{ft}^{2}\right)$. The flush flowed out the waste outlet weir to the waste tank. The waste outlet weir was then sealed, and unloading solution was passed through the column at $1.0 \mathrm{gal} / \mathrm{min}$ to carry the resin slurry out the overflow. This flow rate was not critical and was set only by the pressure drop in the neck of the column and the overflow system. This pressure drop was kept low enough so that it, in combination with the liquid head in the column, did not exceed the maximum seal pressure on either the product weir or waste outlet weir. 


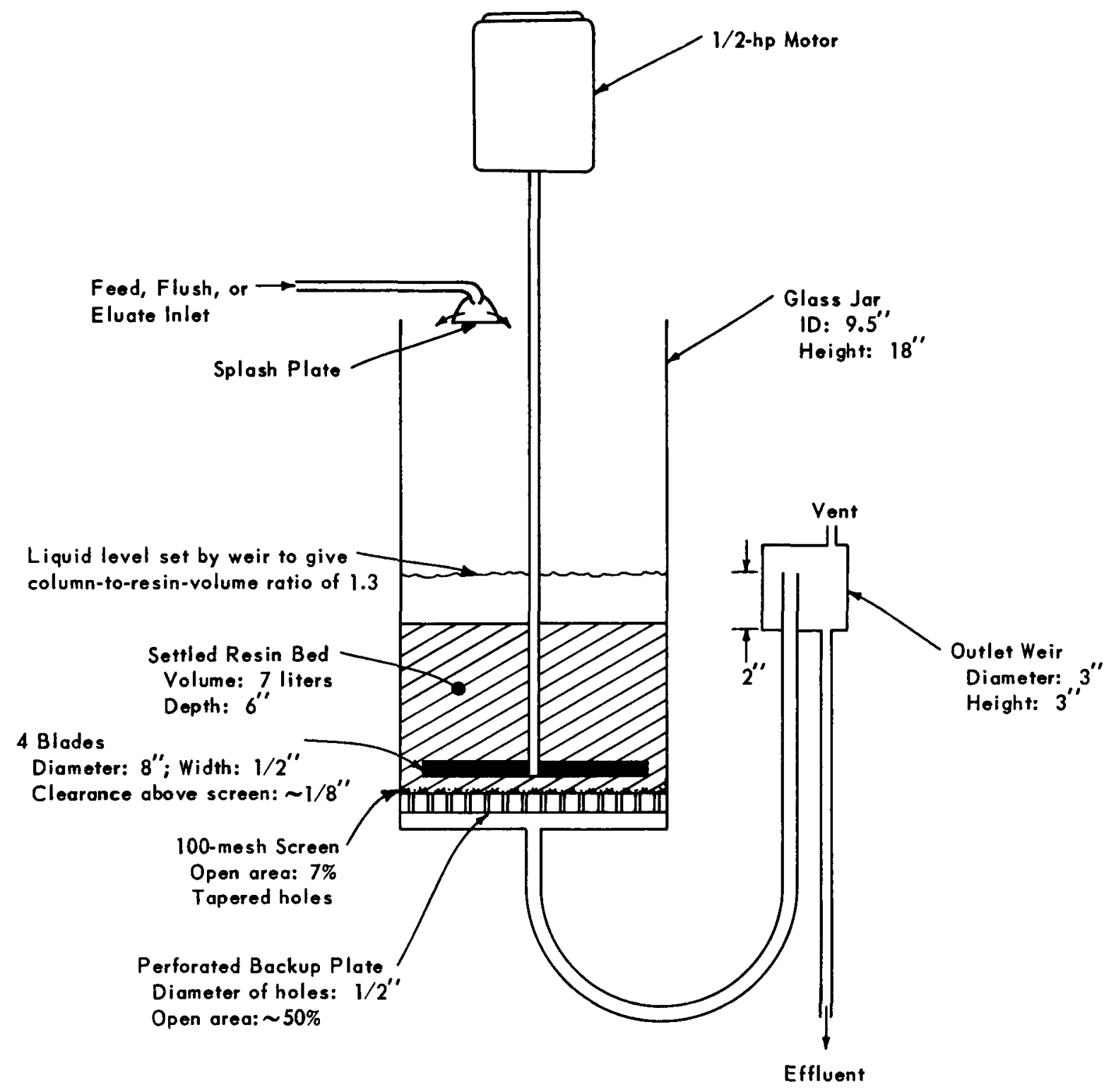

FIG. I EXPERIMENTAL AGITATED BED 


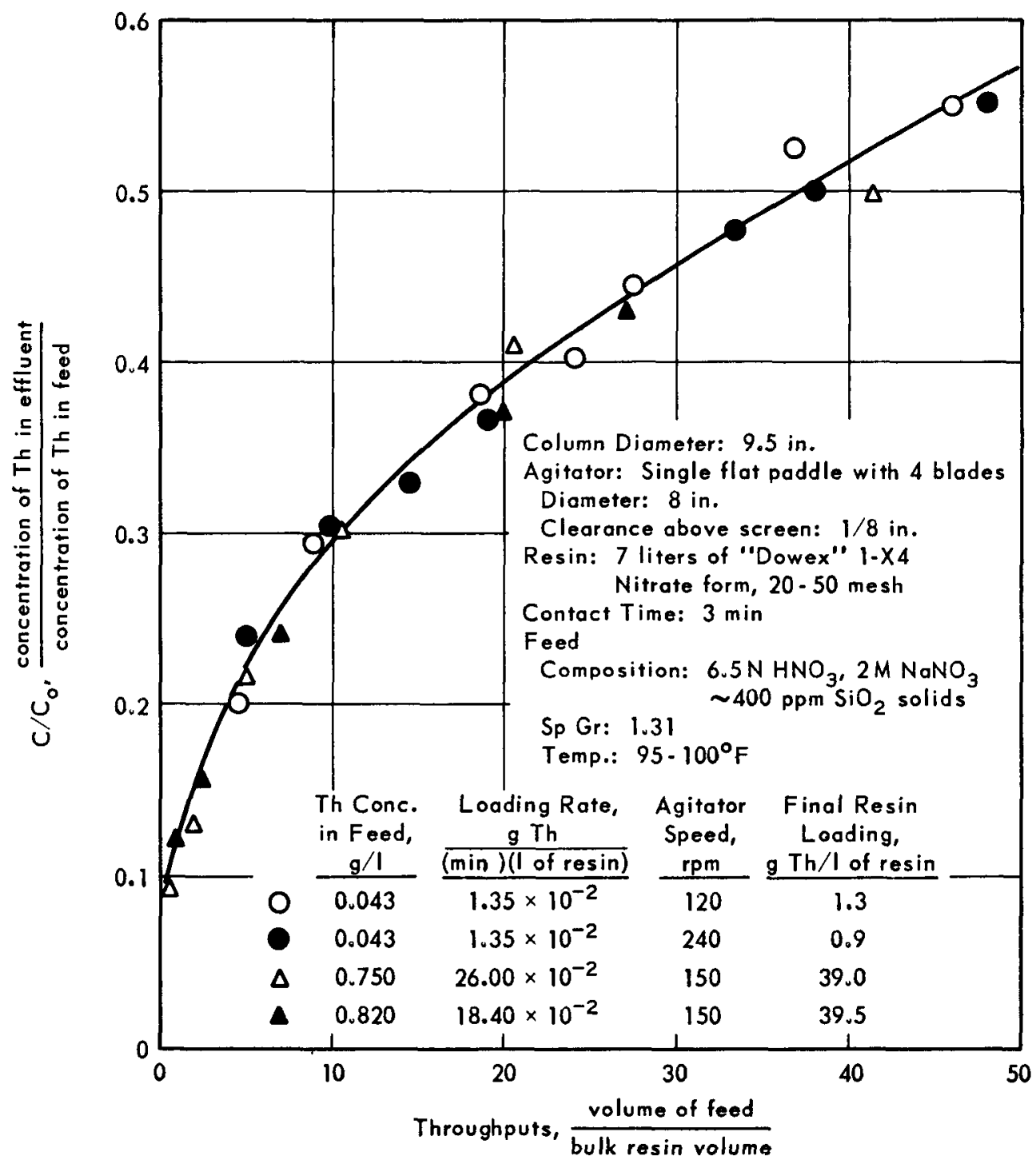

FIG. 2 EFFECT OF AGITATION AND THORIUM CONCENTRATION ON ABSORPTION CHARACTERISTICS 


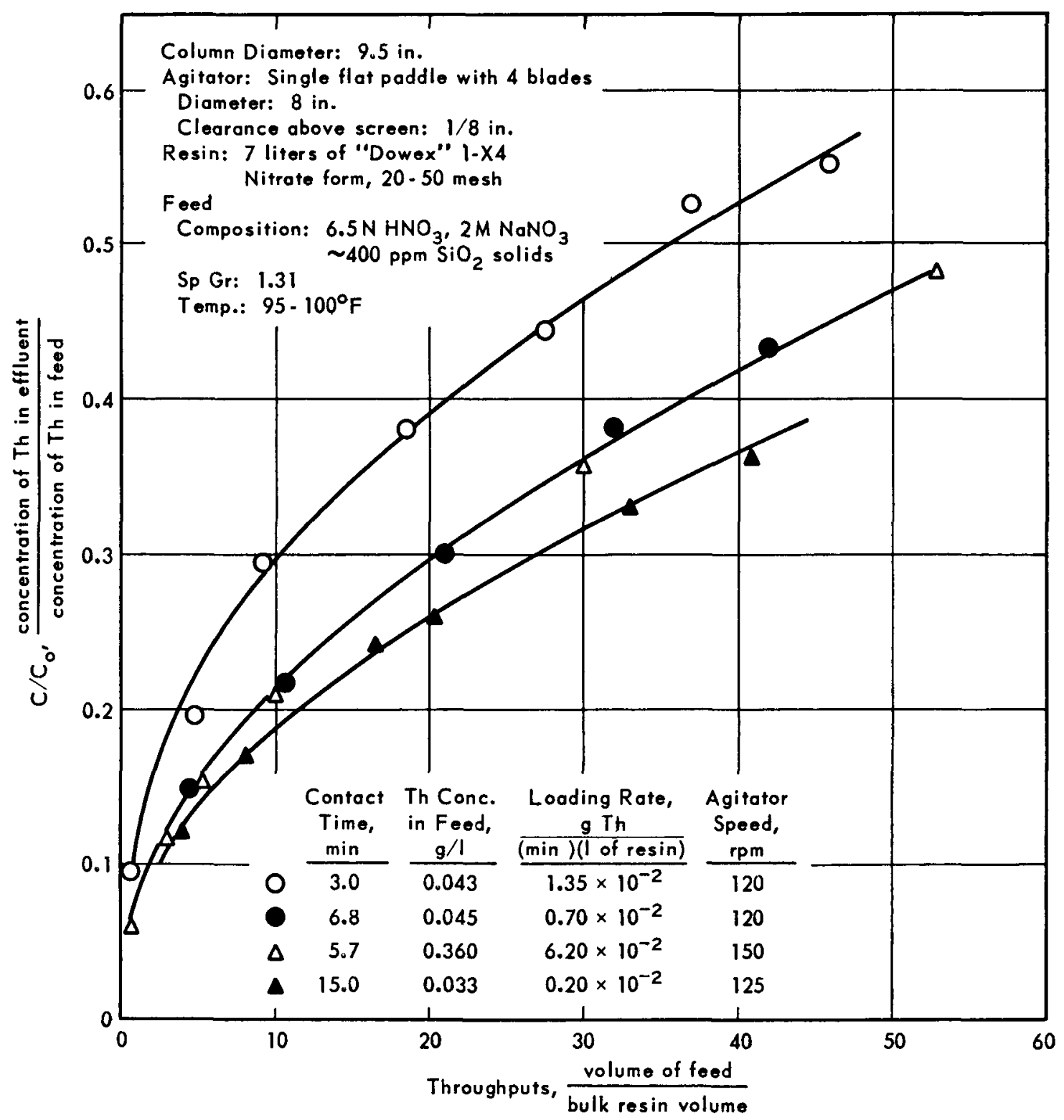

FIG. 3 EFFECT OF CONTACT TIME ON ABSORPTION CHARACTERISTICS 20 TO 50 MESH "DOWEX" I-X4 RESIN 


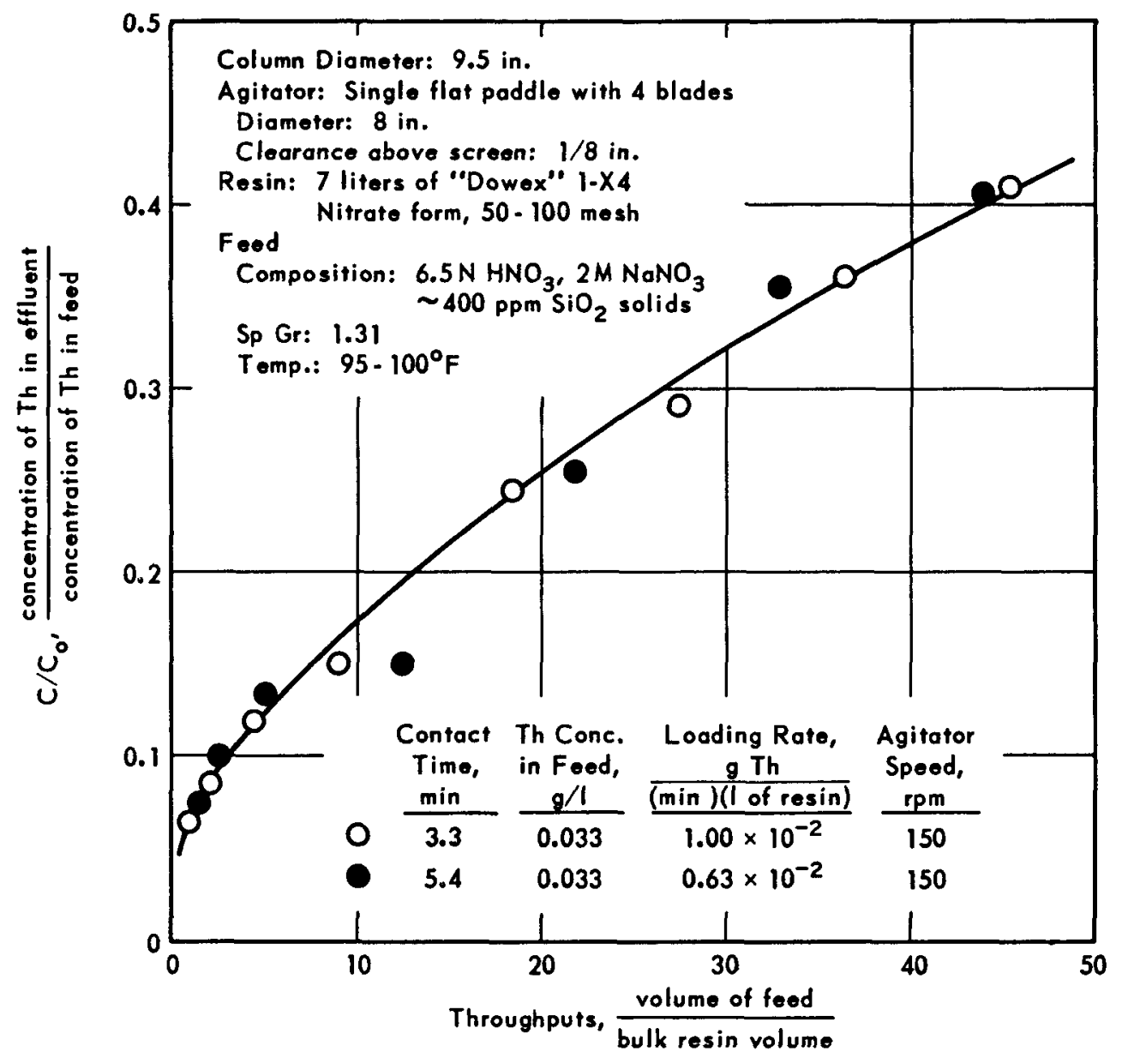

FIG. 4 EFFECT OF CONTACT TIME ON ABSORPTION CHARACTERISTICS 50 TO 100 MESH "DOWEX" 1-X4 RESIN 


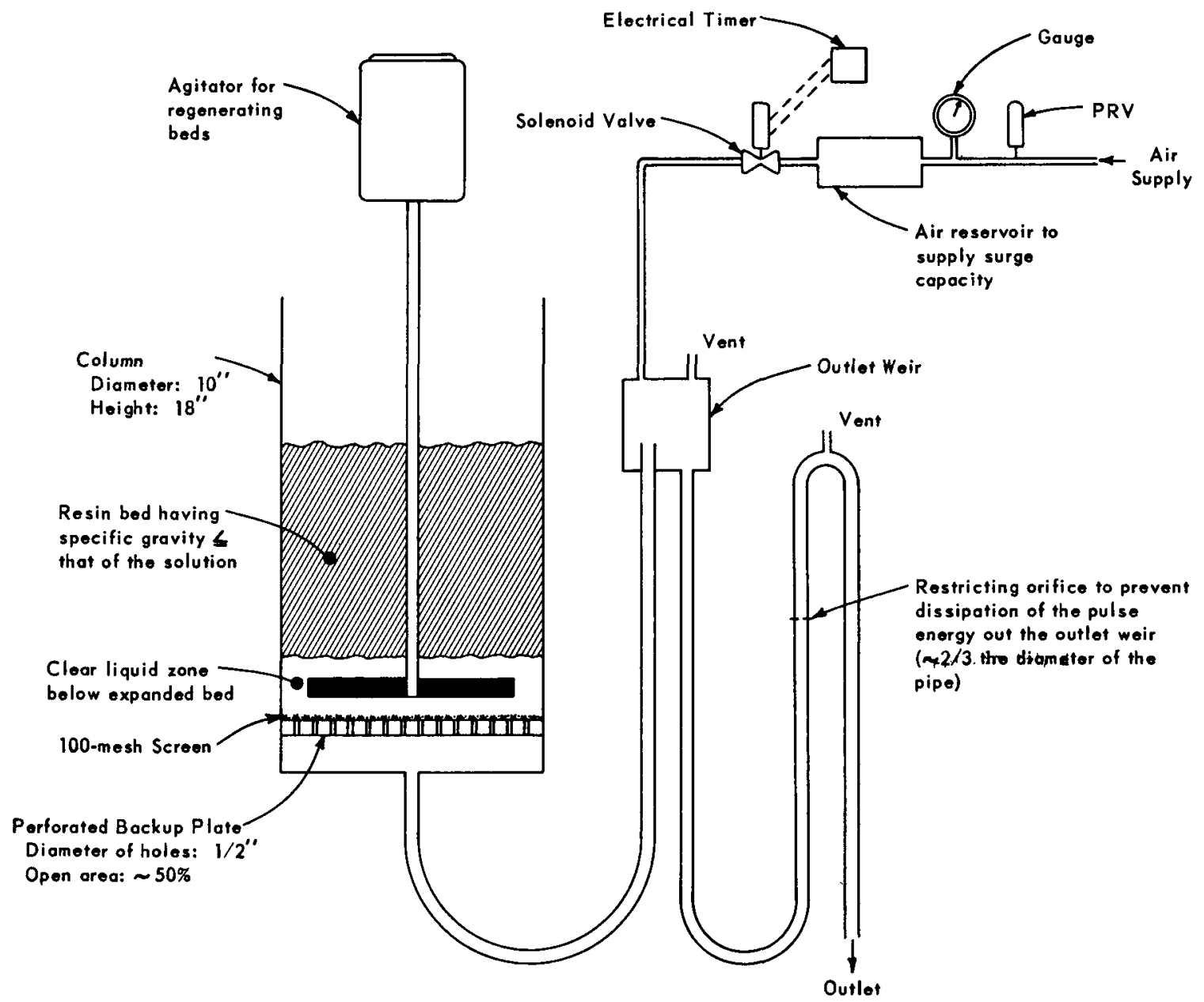

FIG. 5 PULSED ION EXCHANGE COLUMN 


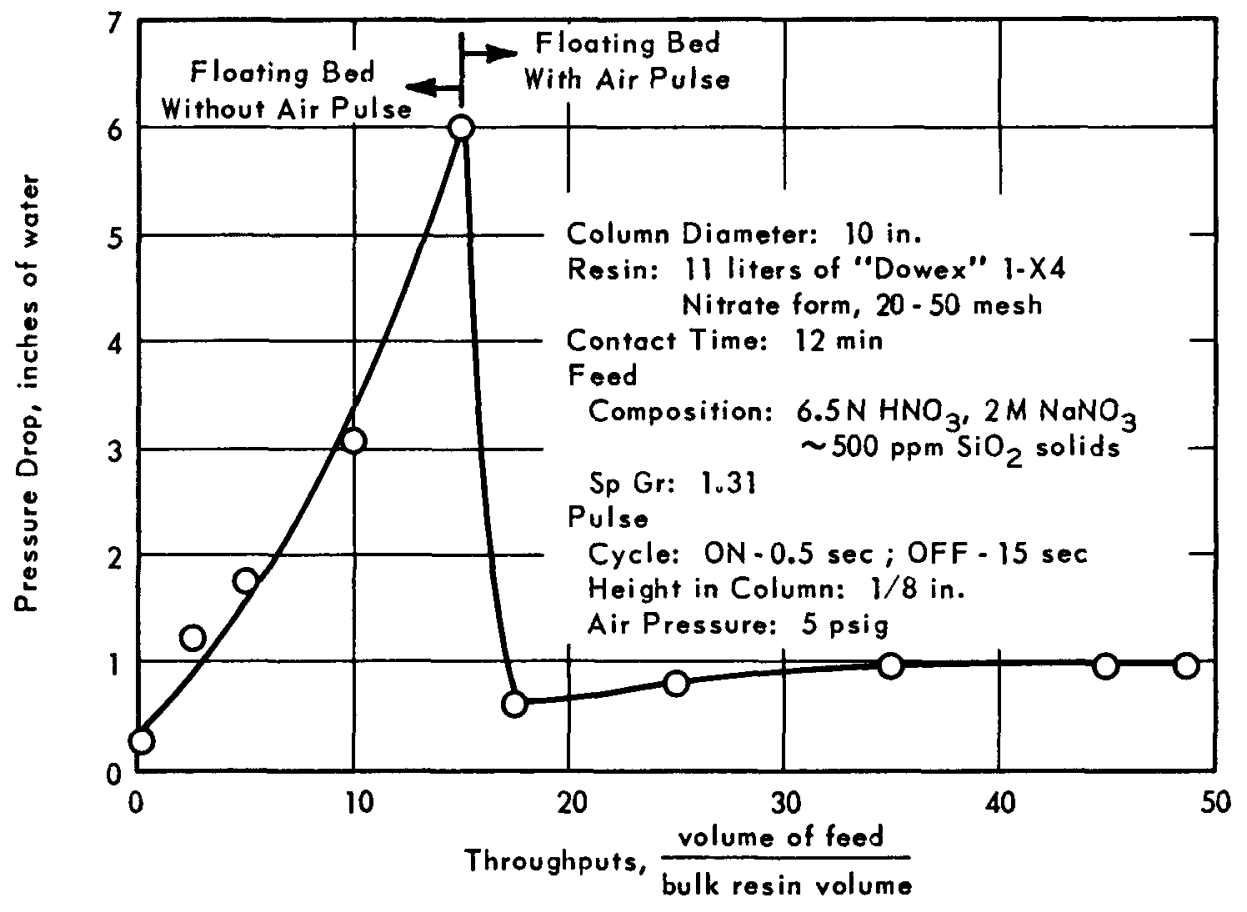

FIG. 6 EFFECT OF AIR PULSE ON COLUMN PLUGGING 


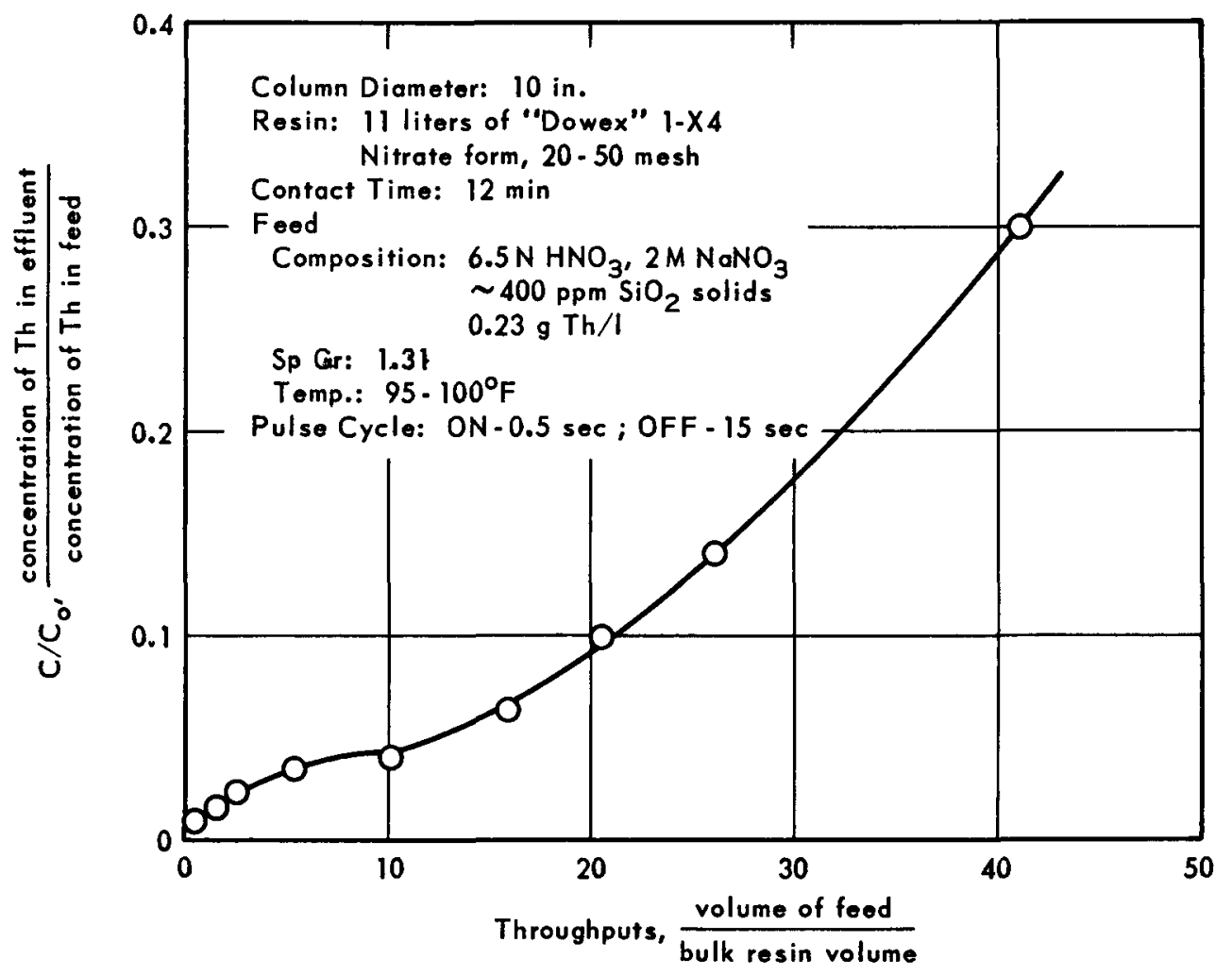

FIG. 7 ABSORPTION CHARACTERISTICS OF A PULSED BED 


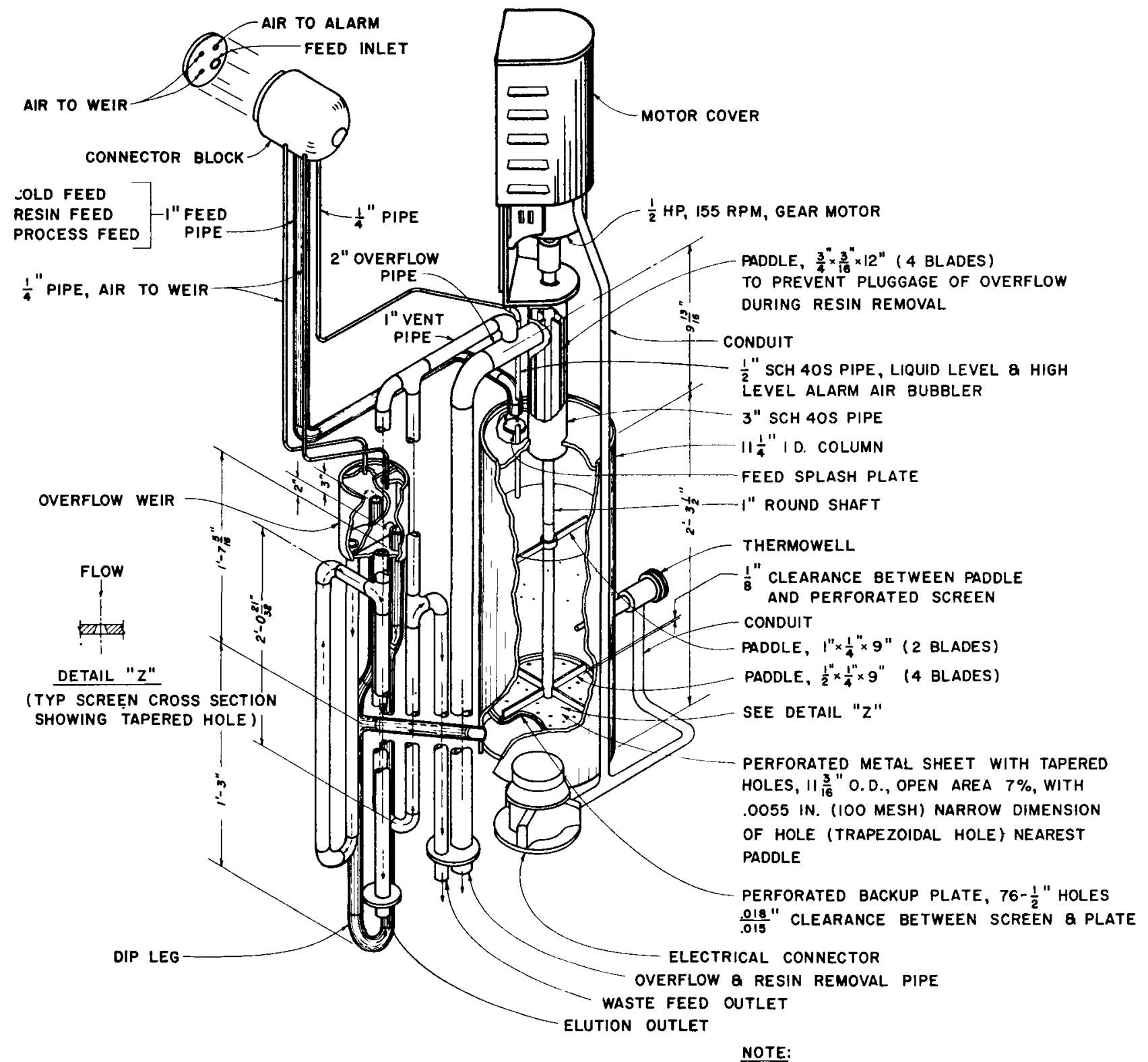

ALL MATERIAL 304L SST.

FIG. 8 PROTOTYPE COLUMN 


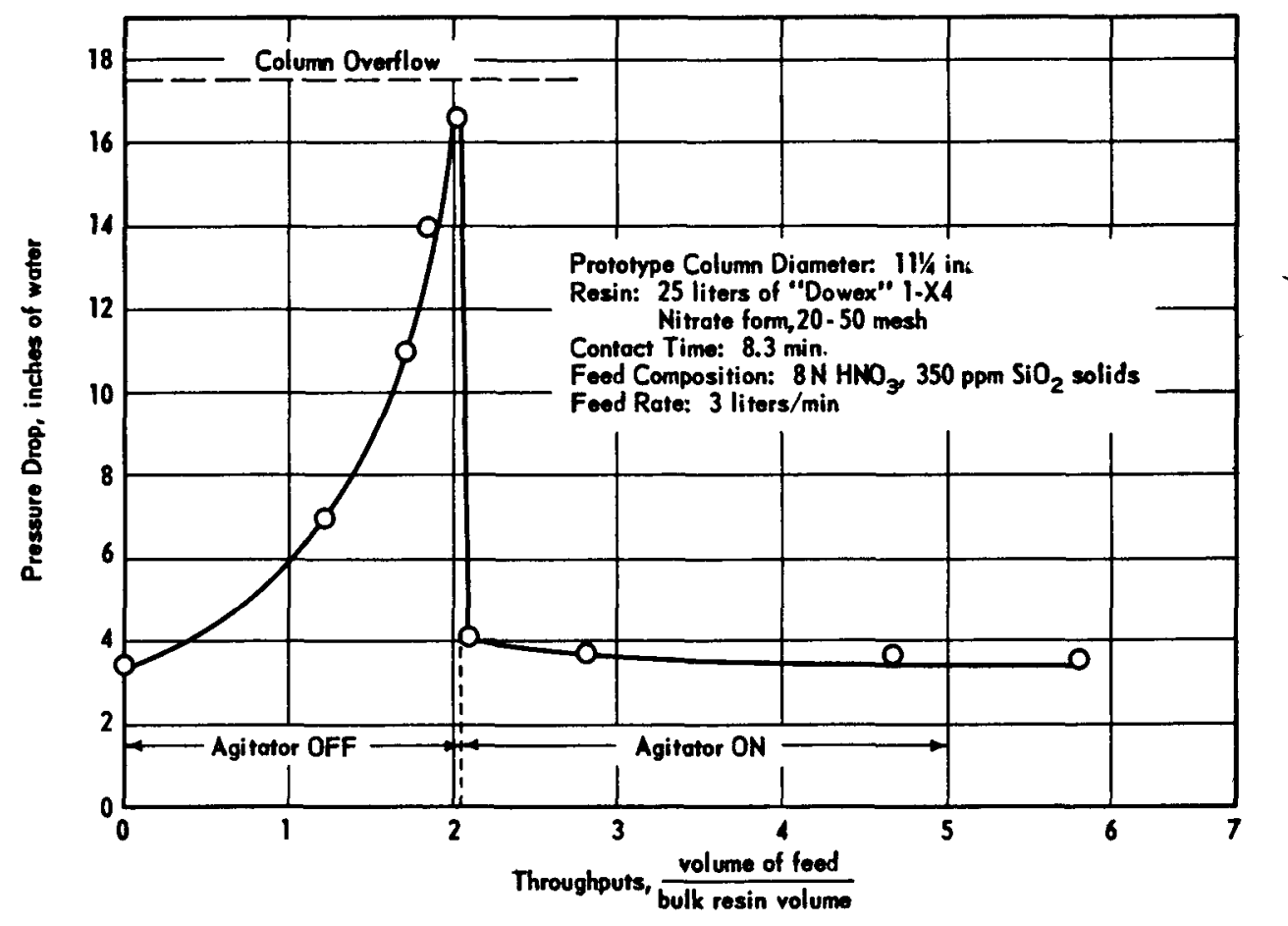

FIG. 9 EFFECT OF AGITATION ON BED PLUGGING 


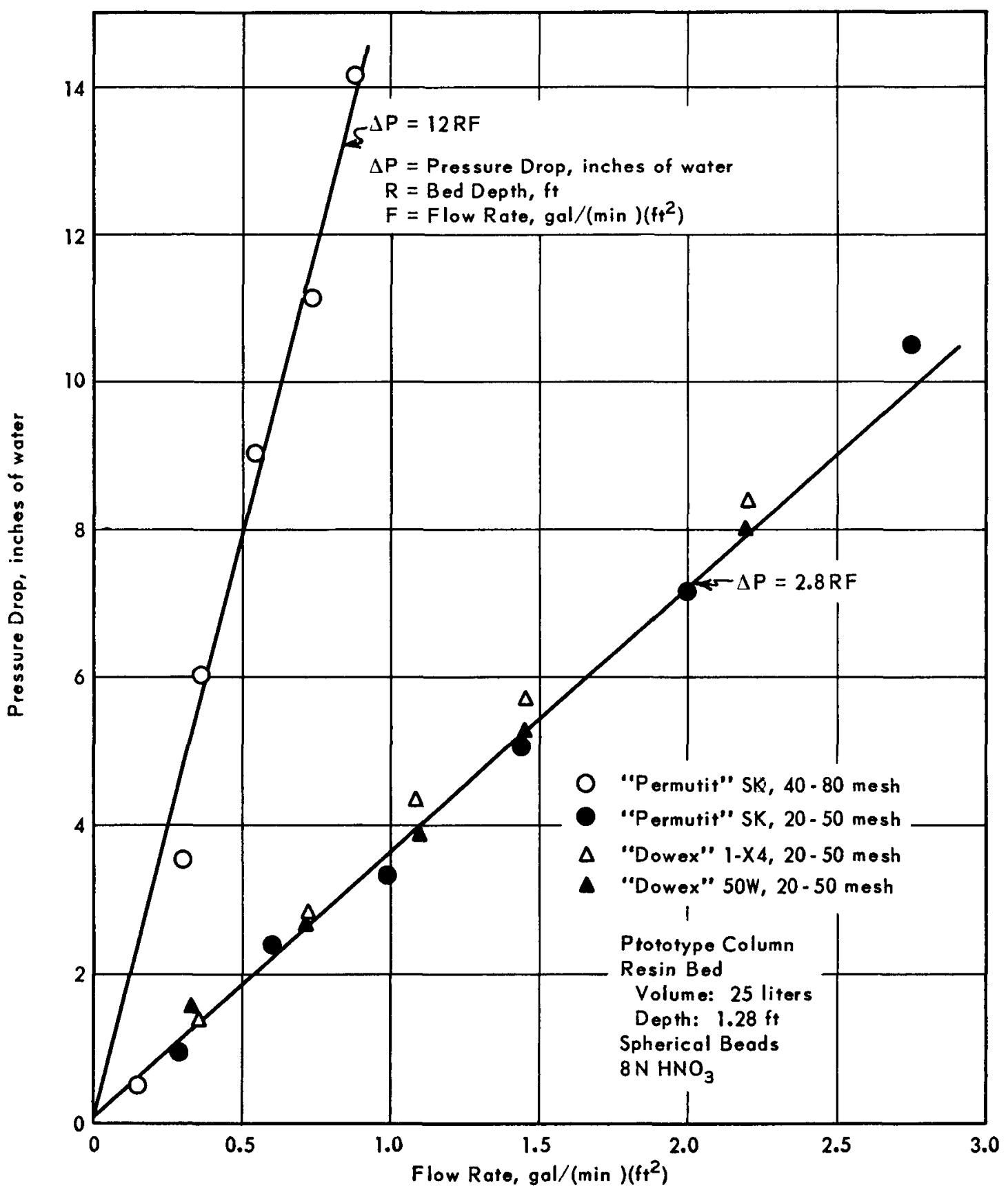

FIG. 10 PRESSURE DROP FOR OPERATION AS A FIXED BED 


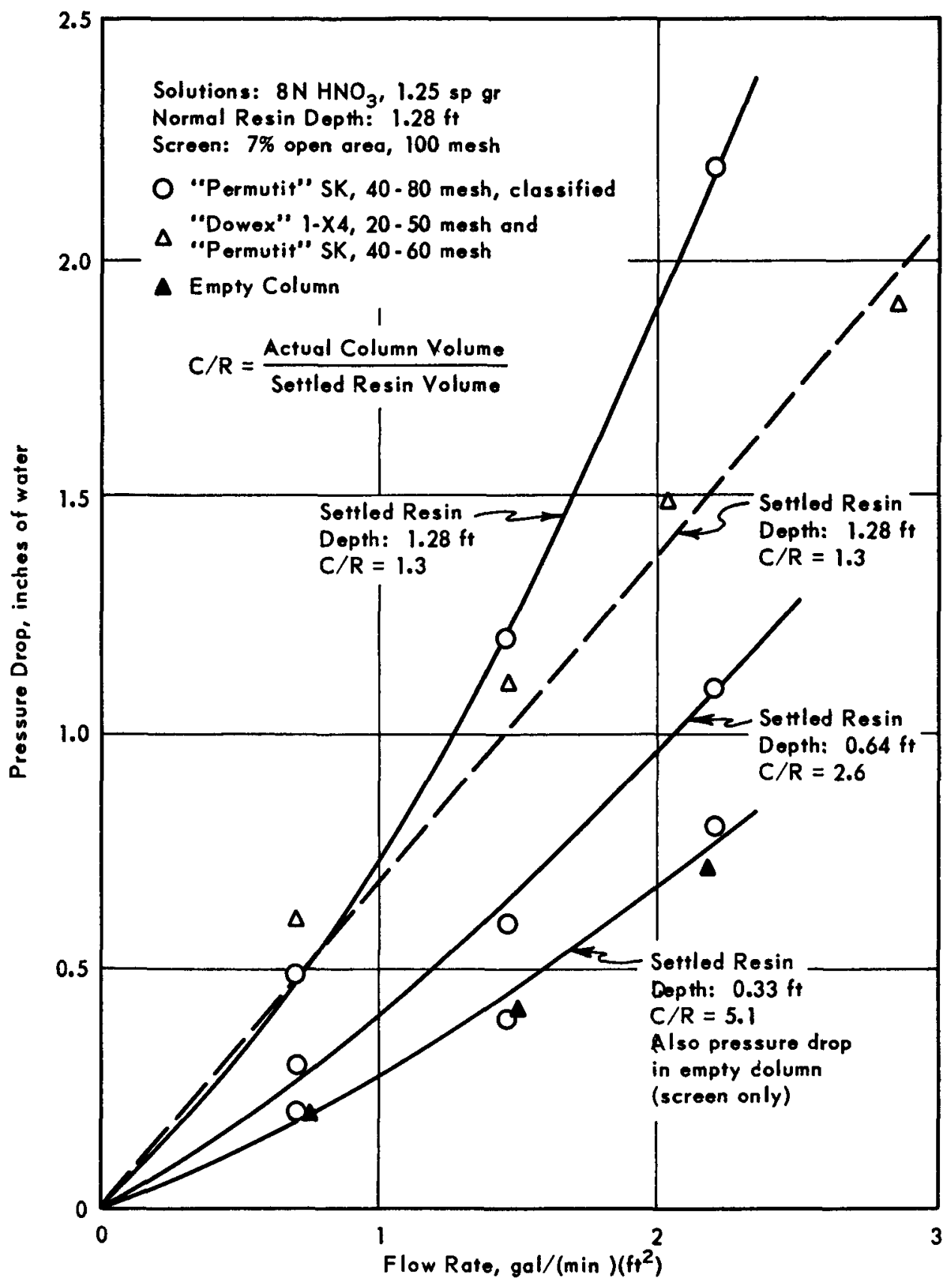

FIG. 11 PRESSURE DROP FOR OPERATION AS AN AGITA TED BED 


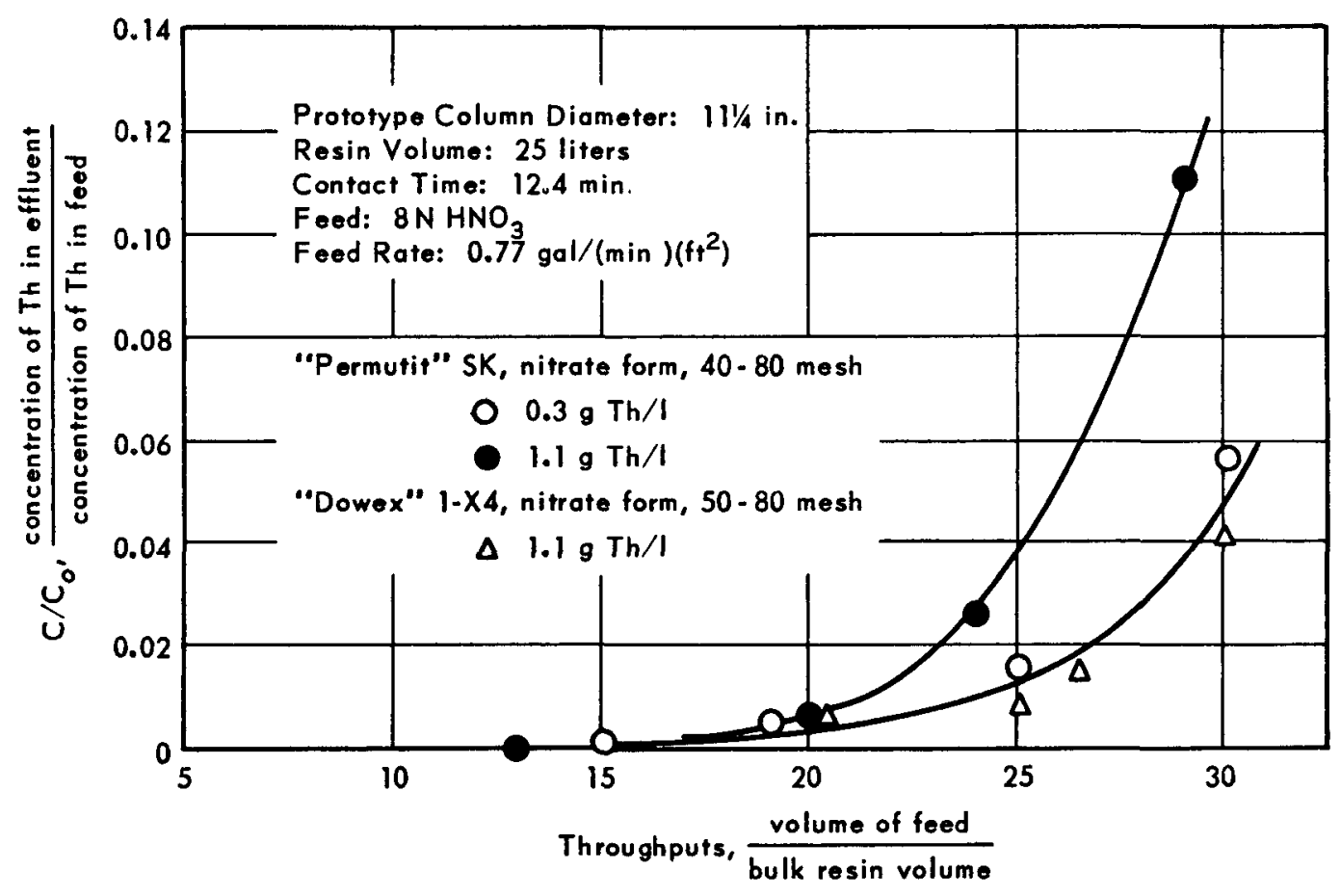

FIG. 12 ABSORPTION CHARACTERISTICS FOR OPERATION AS A FIXED BED 


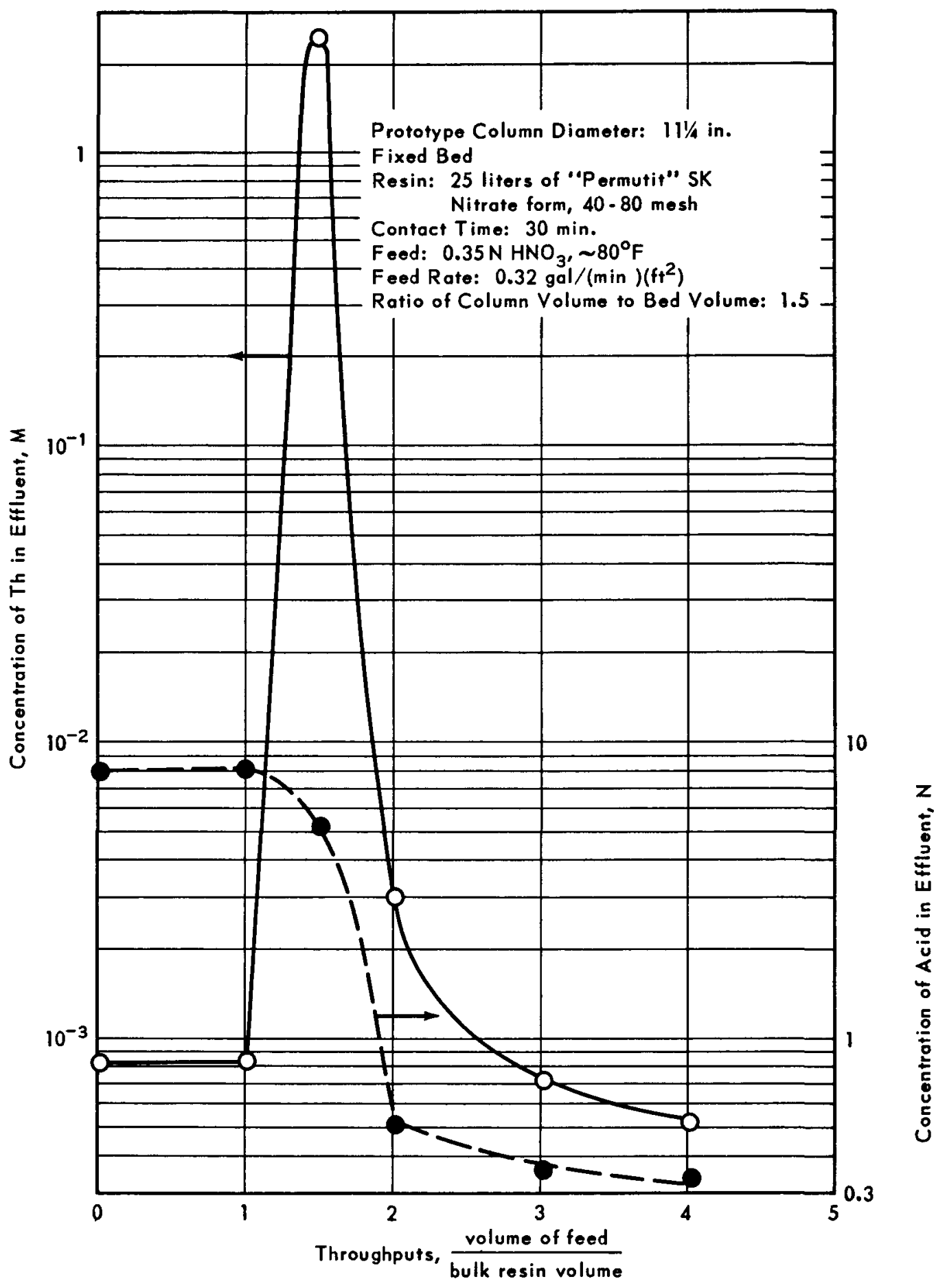

FIG. 13 TYPICAL ELUTION CHARACTERISTICS 


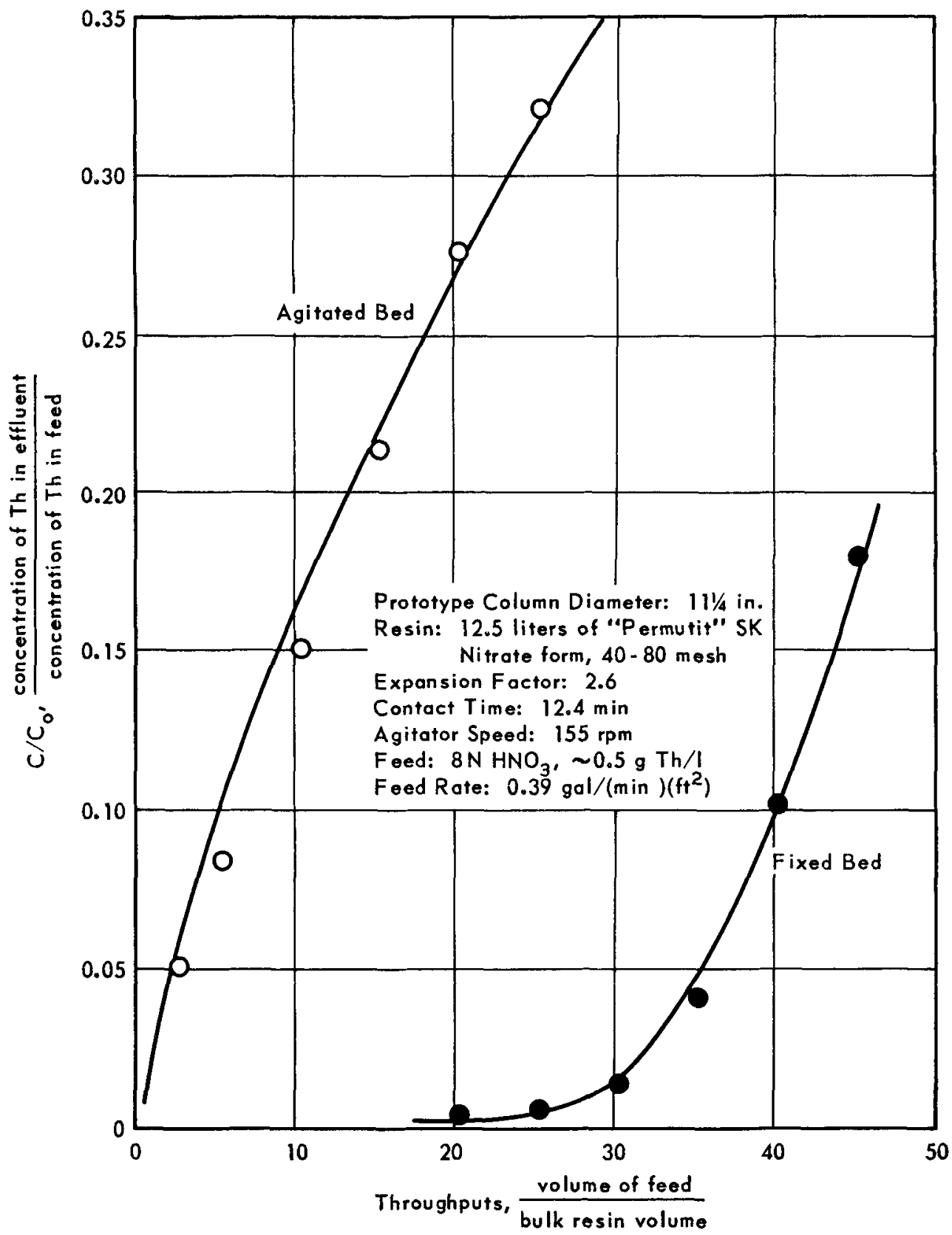

FIG. 14 ABSORPTION CHARACTERISTICS WITH A REDUCED VOLUME OF RESIN 


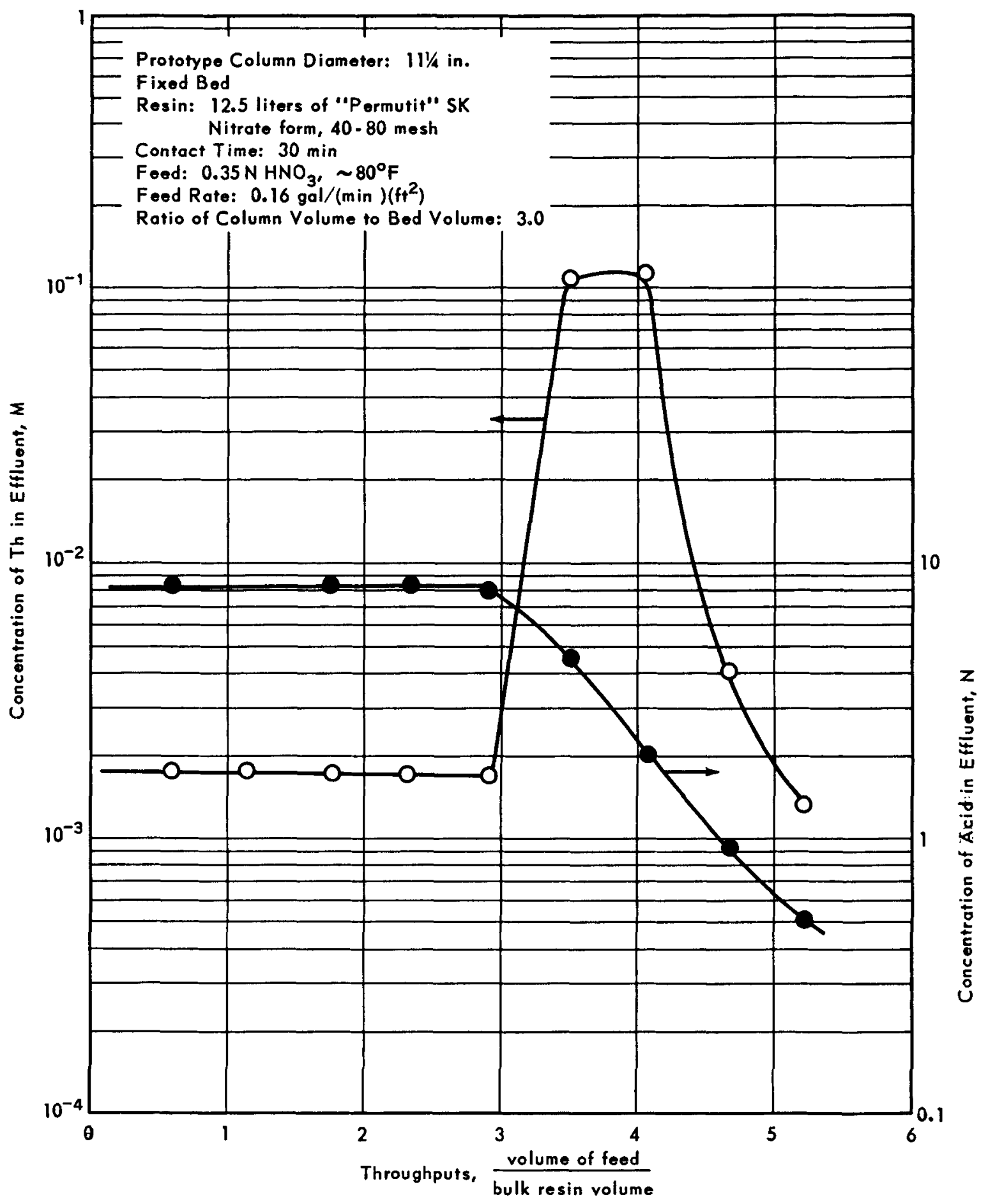

FIG. 15 ELUTION CHARACTERISTICS WITH A REDUCED VOLUME OF RESIN 


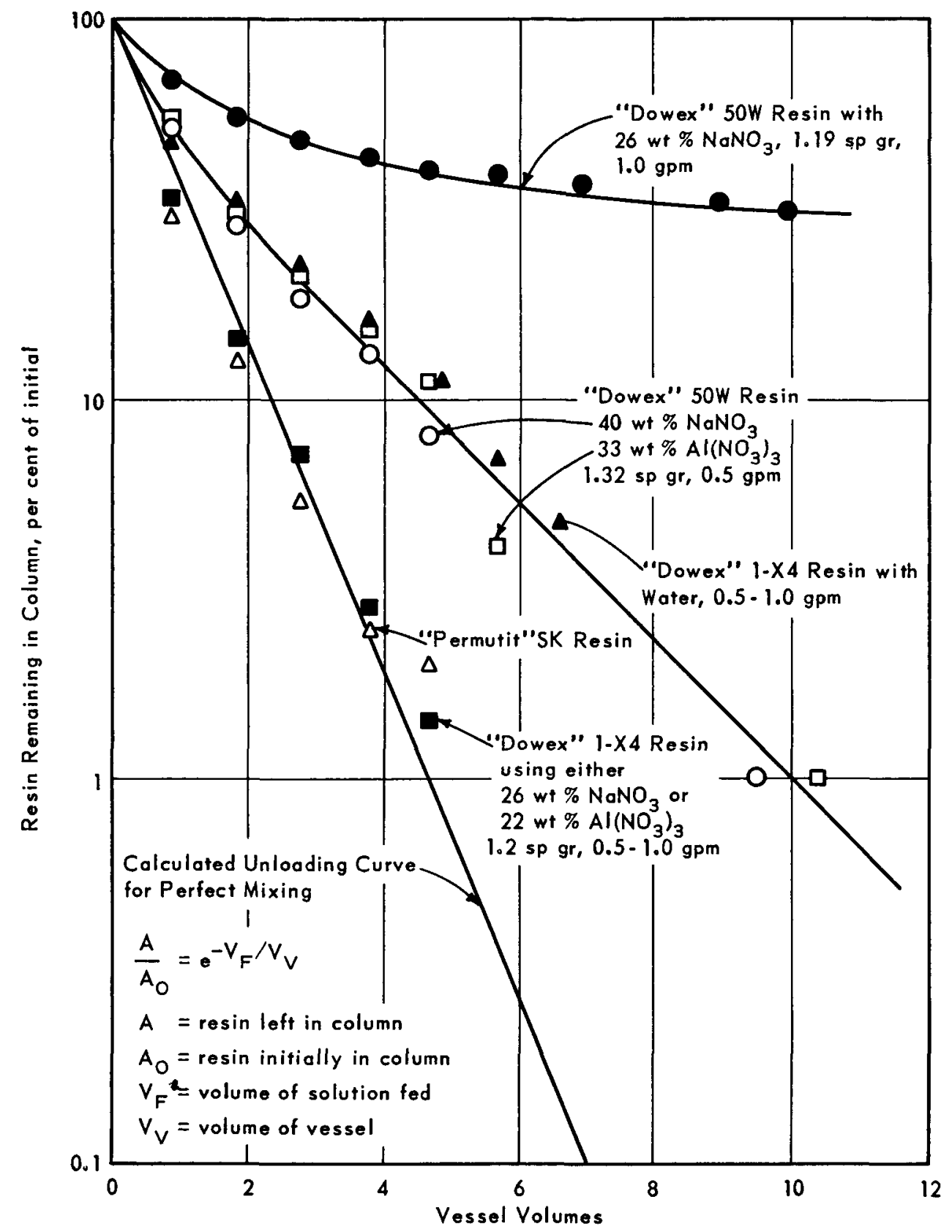

FIG. 16 RESIN UNLOADING 


\section{BIBLIOGRAPHY}

1. Bartels, C. R., et al. "A Novel Ion-Exchange Method for the Isolation of Streptomycin". Chem. Engr. Prog. 54, No. 8, 49-51 (1958).

2. Prout, W. E. and L. P. Fernandez. "Performance of Anton Resin in Ag1tated Beds". Ind. Eng. Chem. 53, No. 6, pp. 449-52 (1961).

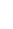

